\title{
Fungsi Dan Makna Sastra Bali Tradisional Sebagai Pembentuk Karakter Diri
}

\author{
Ni Nyoman Karmini \\ Prodi Pendidikan Bahasa dan Sastra Indonesia, Fakultas Pendidikan Bahasa dan Seni, \\ IKIP Saraswati \\ E-mail : ninyomankarmini@yahoo.com
}

\begin{abstract}
Tujuan tulisan ini adalah untuk mendeskripsikan fungsi dan makna yang diungkapkan dalam sastra Bali tradisional. Setiap karya sastra memiliki fungsi dan makna yang dapat memberikan kesenangan dan manfaat (dulce et utile) bagi penikmatnya. Demikian juga halnya dengan karya sastra Bali tradisional. Fungsi sastra Bali tradisional adalah untuk memberi hiburan dan mendidik. Makna yang terdapat di dalamnya memberikan manfaat untuk membentuk karakter pada penikmatnya. Pendekatan pragmatik dan hermeneutik digunakan untuk memperoleh data dan hasilnya disajikan secara deskriptif dengan teknik induktif-deduktif.
\end{abstract}

Kata kunci: sastra Bali tradisional, fungsi, makna, karakter manusia

\section{Function And Meaning Of Balinese Literature Forming The Character Of Human}

The purpose of this paper is to describe the function and meaning expressed in the traditional Balinese literature. Every literary work has a function and meaning that can give pleasure and benefits (dulce et utile) for the audience. Similarly, traditional Balinese literature. Traditional Balinese literary function is to entertain and educate. Meaning contained therein provide benefits to shape the character of the audience. Pragmatic and hermeneutic approach is used to obtain the data and the results are presented descriptively with inductive-deductive techniques.

Keywords : Balinese literature, function, meaning, human character

Proses Review : 19 April - 4 Mei 2017, Dinyatakan Lolos : 8 Mei 2017

\section{PENDAHULUAN}

Fakta, manusia baru dapat hidup dengan baik apabila hidup bermasyarakat. Dalam kehidupan bermasyarakat terdapat asas kekeluargaan yang kuat, karena pada dasarnya manusia merupakan makhluk pribadi dan sekaligus makhluk sosial. Merupakan fakta juga, bahwa dewasa ini krisis moral dan akhlak melanda kehidupan masyarakat. Salah perkataan, sengaja maupun tidak sengaja menimbulkan permasalahan yang panjang. Hal ini sebenarnya dapat diatasi dengan pengendalian diri dan pembinaan watak walaupun butuh waktu. Untuk pembinaan watak salah satunya dapat dilakukan atau diterapkan lewat pembelajaran sastra, baik di sekolah maupun di rumah.Artinya, lewat materi sastra ajaran moral disampaikan secara jujur dan benar, karena sebuah karya sastra bersumber dari kenyataan-kenyataan yang hidup dalam masyarakat (realitas-objektif). Karya sastra tidak hanya mengungkapkan realitas objektif melainkan juga mengungkapkan nilai-nilai. Karya sastra bukan semata-mata tiruan dari alam (imitation of nature) atau tiruan dari hidup (imitation of life), tetapi juga merupakan penafsiran-penafsiran tentang alam dan kehidupan itu (interpretation of life). Karya sastra mengungkapkan masalah-masalah manusia dan kemanusiaan, tentang makna hidup dan kehidupan. Sastra melukiskan penderitaan-penderitaan manusia, perjuangannya, kasih sayangnya, nafsunya, dan segala sesuatu yang dialaminya. Lewat karya sastra, pengarang ingin menampilkan nilai-nilai yang lebih 
tinggi dan lebih agung. Lewat karya sastra dapat menafsirkan tentang makna hidup dan hakikat hidup (Karmini, 2011:2).

Karya sastra memuat nilai-nilai keindahan dan kebenaran. Di dalamnya termuat nilai-nilai hedonik, nilai artistik, nilai kultural, nilai etis-moralreligius, dan nilai praktis. Nilai hedonik, yaitu nilai yang memberikan kesenangan secara langsung kepada pembaca atau pendengarnya; nilai artistik, yaitu suatu karya dapat memanifestasikan suatu seni atau keterampilan seseorang; nilai kultural, yaitu suatu karya mengandung hubungan yang mendalam dengan suatu masyarakat dan atau suatu peradaban, kebudayaan; nilai etis-moral-religius, yaitu suatu karya sastra memancarkan ajaran-ajaran yang ada sangkut pautnya dengan etika, moral, dan agama; dan nilai praktis, yaitu karya sastra mengandung hal-hal yang praktis yang dapat dilaksanakan dalam kehidupan sehari-hari) (dalam Karmini, 2011:1-2; 2015).

Pada dasarnya, karya sastra memiliki peranan penting dalam hidup dan kehidupan manusia, memiliki manfaat untuk membimbing manusia ke arah yang lebih positif. Teeuw (2003:21); Karmini (2008) menyatakan sastra adalah alat untuk mengajar, buku petunjuk, buku instruksi atau pengajaran. Dengan membaca karya sastra, pembaca dibuat merenungkan masalah kehidupan, yang pada akhirnya dapat mengasah batinnya, menjadi lebih peka, berbudaya, serta dapat menghargai apa yang dimilikinya serta dimiliki oleh orang lain. Dengan membaca karya sastra, pembaca dapat mempelajari keindahan dalam karya, baik keindahan bahasa maupun keindahan suatu pemikiran. Melalui karya sastra, pembaca dapat belajar mengenai pengalaman yang dialami sang tokoh cerita, baik pengalaman yang baik maupun pengalaman yang buruk. Dengan merenungkan pengalaman-pengalaman sang tokoh cerita, pembaca dapat menentukan sikap, dapat menentukan pilihan hidup dan kehidupan yang dicita-citakannya.

Melalui karya sastra, baik tradisional maupun modern dapat diketahui gambaran kehidupan budaya pada masanya, karena sastra sebagai wahana untuk pengungkapan pikiran, gagasan, perasaan, dan kepercayaan.

Aspek budaya yang tercermin pada karya sastra, antara lain: agama, bahasa, sastra, seni, dan tradisi lingkungan karya sastra itu diciptakan (Karmini, 2008; 2011; 2012). Pengetahuan yang diperoleh dari karya sastra dapat membantu dalam mempelajari dan mengetahui perkembangan budaya suatu bangsa, yang bermanfaat bagi kehidupan ini dan bagi generasi berikutnya dalam rangka pembangunan diri sendiri, masyarakat, dan bangsa yang mandiri.

Setiap kelompok masyarakat memiliki hasil karya sastra, baik karya sastra tradisional maupun karya sastra modern. Seperti misalnya Bali. Bali yang dijuluki pulau seribu pura (Karmini, 2011) banyak memiliki dan menyimpan hasil karya sastra bermutu, baik karya sastra tradisional (Bali Purwa) maupun karya sastra modern (Bali Anyar). Salah satu karya sastra tradisional (Bali Purwa) adalah geguritan (dalam Karmini, 2008). Geguritan termasuk ke dalam kelompok tutur/tatwa/filsafat atau kelompok itihasa, karena geguritan berisi nasihat tentang moral yang dapat dijadikan pedoman dalam menjalani hidup dan kehidupan ini (Suwija, 1979: 10); Karmini (2008). Sastra modern yang berbahasa Bali, perkembangannya juga menarik, terbukti dengan terusnya terbit puisi, cerpen, dan novel berbahasa Bali, dan setiap tahun pengarang dan pembinanya mendapat Hadiah Sastra Rancage (Putra, 2010); (Karmini, 2015). Untuk sastra modern berbahasa Indonesia, hal yang menakjubkan juga terjadi, terbukti dari seringnya sastrawan Bali mendapat hadiah sastra bergengsi seperti Khatulistiwa Award, seperti yang diperoleh pengarang Gde Aryantha Soethama, Sindhu Putra, dan Oka Rusmini (Putra, 2011; Karmini, 2015). Dapat dikatakan bahwa Bali memberikan kontribusi penting dalam perkembangan sastra Indonesia (Karmini, 2015).

Karya sastra Bali tradisional sampai di tahun 2000an masih ditulis sehingga menarik diapresiasi dan diteliti (Karmini, 2008; 2012; 2016). Tulisan ini menggunakan geguritan sebagai objek kajian. Geguritan masih berkembang sampai saat ini pada masyarakat Bali dalam arti masih dihayati. Geguritan termasuk karya sastra berbentuk puisi (tembang). Geguritan memuat kode bahasa, kode sastra, dan kode budaya (Karmini, 2008; 2012). Geguritan dibentuk oleh pupuh-pupuh, mengikuti persyaratan (padalingsa), dan biasanya menggunakan tembang macapat atau sekar alit dalam penyampaiannya (dalam Karmini, 2008; 2012). 
Padalingsa meliputi: sejumlah silabel atau suku kata dalam tiap-tiap baris (carik); jumlah baris pada tiap-tiap bait (pada); dan bunyi akhir tiap-tiap baris (dalam Karmini, 2008; 2012).

Geguritan sarat dengan pedoman-pedoman kehidupan, tentang etika, dan moral. Pedoman-pedoman kehidupan yang termuat di dalamnya dapat dipahami oleh pembaca lewat pembacaan biasa, tetapi menjadi semakin mudah diresapi oleh pendengarnya apabila disampaikan lewat tembang (dinyanyikan), baik dilakukan oleh perorangan maupun oleh kelompok santi (sekaa santi). Kebiasaan matembang melahirkan konsep "malajah sambilang magending, magending sambilang malajah" (belajar sambil menyanyi, menyanyi sambil belajar) (Putra, 2009; Karmini, 2008:3; 2012; 2015)

Dalam geguritan, ajaran-ajaran moral dalam agama Hindu dituangkan dalam kisah kehidupan sang tokoh cerita. Dari perilaku sang tokoh cerita itulah dapat dipetik suatu pembelajaran moral, yang tentunya berupa moral yang baik sesuai ajaran agama, yang berlaku untuk semua manusia di muka bumi ini. Perilaku-perilaku baik sang tokoh cerita semestinya dapat ditiru dan dijadikan contoh. Pembelajaran moral yang baik dari sebuah kisah cerita dapat dipetik dan dijadikan pedoman dalam menjalankan kehidupan ini sehingga mencerminkan karakter diri. Karakter diri biasanya dibentuk oleh budaya di sekitarnya (budaya daerah), sedangkan karakter bangsa Indonesia dibentuk oleh budaya-budaya daerah yang ada di wilayah Indonesia. Membangun karakter diri dan karakter bangsa dapat dilakukan dengan merunut dan mencontoh atau meneladani kearifan lokal (nilai-nilai budi pekerti yang adiluhung), seperti yang termuat dalam karya sastra daerah yang berbentuk geguritan.

Geguritan sangat menarik untuk dikaji sebab sangat kaya nilai-nilai/pedoman-pedoman kehidupan yang terkandung di dalamnya. Ketertarikan itu diwujudkan dalam tulisan ini. Geguritan yang dikaji adalah Geguritan Dreman. Dalam Geguritan Dreman tersurat dan tersirat/tercermin suatu cara untuk mempertahankan harkat, martabat, dan jati diri. Kecantikan fisik bila dijadikan fokus, bila dijadikan sesuatu yang sangat membanggakan, tanpa didukung kekuatan moral dan iman yang kuat, maka besar kemungkinan mendorong untuk menjadi sombong dan angkuh.
Hal ini sangat menarik dikaji dan diangkat kepermukaan untuk dijadikan sebuah contoh yang patut dijadikan pedoman dalam membentuk karakter manusia, mengingat kehidupan pada era modern ini banyak sekali tawaran-tawaran kehidupan yang menarik, menggiurkan, atau mungkin menyesatkan. Keliru mengambil keputusan akan terjadi kekacauan kehidupan.

Sehubungan dengan uraian di atas, maka permasalahan yang muncul dari tulisan ini, adalah berkaitan dengan fungsi dan makna yang tersirat dalam Geguritan Dreman. Dengan demikian, tujuan tulisan ini, adalah untuk mendeskripsikan fungsi dan makna yang tersirat dalam Geguritan Dreman. Untuk dapat mendeskripsikan fungsi dan makna yang tersirat di dalamnya, digunakan metode dokumentasi dengan teknik catat, dan dianalisis dengan metode hermeneutika. Selanjutnya, data disajikan secara deskriptif dengan teknik induktifdeduktif.

\section{Teori Fungsi}

Berkaitan dengan teori fungsi, sangat penting dipahami terlebih dahulu mengenai makna kata fungsi. Dalam Kamus Besar Bahasa Indonesia (KBBI) ditemui paparan bahwa "fungsi artinya ... "kegunaan suatu hal" (Alwi, 1996:281). Berkaitan makna kata fungsi, maka dipaparkan beberapa pendapat mengenai fungsi sesuatu (dalam Karmini, 2002:20-22). Bandem dan Murgiyanto (1996:20) menyatakan bahwa fungsi teater daerah, adalah (1) sebagai sarana upacara, (2) sebagai hiburan, (3) sebagai media komunikasi, dan (4) sebagai pengucapan sejarah. Dundes dalam Danandjaja (1997) menyatakan bahwa fungsi foklor, adalah (1) sebagai alat pendidik, (2) sebagai pelipur lara, (3) sebagai protes sosial, (4) sebagai proyeksi keiinginan terpendam. Bascom (1965) dalam Danandjaja (1997), fungsi foklor, adalah (1) sebagai sistem proyeksi, yakni sebagai alat pencerminan anganangan suatu kolektif, (2) sebagai alat pengesahan pranata-pranata dan lembaga-lembaga kebudayaan, (3) sebagai alat pendidikan anak, dan (4) sebagai alat pemaksa dan pengawas agar norma-norma masyarakat selalu dipatuhi anggota kolektifnya. Teeuw (1984) menyatakan, sastra lisan dari dahulu sampai sekarang masih tetap diciptakan dan dihayati oleh masyarakat di samping bentuk secara tulis. Kedua sastra tersebut hidup berdampingan 
dan sering ada keterpaduan atau keterjalinan antara yang satu dengan yang lainnya. Sastra diturunkan dalam bentuk sastra tulis dan dalam prakteknya berfungsi sebagai sastra yang dibacakan dan dibawakan bersama-sama, jadi sebagai performing art. Sebaliknya, sastra lisan kemudian ditulis dan dijadikan sastra tulis, atau kebiasaan sastra lisan masih terasa dalam perkembangan sastra tulis sampai ke puisi modern. Dengan demikian, dalam penelitian sastra tulis dan perkembangannya sangat diperlukan pengetahuan tentang struktur dan fungsi sastra lisan. Interaksi yang terus-menerus menyebabkan ciri-ciri khas dan konvensi sastra lisan mutlak perlu untuk teori sastra umum. Merton (dalam Kaplan dan Manners, (2002), memaparkan fungsi budaya dibedakan menjadi dua, yaitu fungsi manifest dan fungsi laten (fungsi tampak dan fungsi terselubung) dalam suatu tindak dan unsur budaya. Fungsi manifest adalah konsekuensi objektif yang memberikan sumbangan pada penyesuaian sistem yang dikehendaki yang disadari oleh partisipan sistem tersebut, sedangkan fungsi laten adalah konsekuensi objektif dari ihwal budaya yang tidak dikehendaki maupun disadari oleh warga masyarakat.

Dari beberapa pendapat mengenai teori fungsi di atas, semua pendapat tersebut sangat tepat mengacu pada arti kata fungsi. Sehubungan teori fungsi, tulisan ini mengacu pada teori fungsi budaya menurut Merton, yang meliputi fungsi manifest dan fungsi laten.

\section{Teori Semiotik}

Untuk memperoleh fungsi dan makna yang tersirat dalam Geguritan Dreman digunakan teori semiotik. Semiotik adalah ilmu tentang tanda-tanda. Semiotik menganggap bahwa fenomena sosial/masyarakat dan kebudayaan merupakan tanda-tanda. Semiotik mempelajari sistem-sistem, aturan-aturan, dan konvensi-konvensi yang memungkinkan tandatanda tersebut mempunyai arti. Dalam lapangan kritik sastra, penelitian Semiotik meliputi analisis sastra sebagai sebuah penggunaan bahasa yang tergantung pada (ditentukan oleh) konvensikonvensi tambahan dan meneliti ciri-ciri (sifatsifat) yang menyebabkan bermacam-macam cara (modus) wacana mempunyai makna (Preminger dalam Pradopo, 1995: 119).
Saussure (dalam Pradopo, 1995:119), menyatakan bahwa tanda mempunyai dua aspek, yaitu penanda (signifier) yang menandai bentuk formalnya dan petanda (signified), yaitu arti dari penanda tersebut. Charles Sander Peirce (dalam Luxemburg, 1992: 44-46; Pradopo, 1995: 119-120), tanda ada bermacam-macam berdasarkan pada hubungan antara penanda dan petandanya. Jenis tanda yang utama adalah ikon, indeks, dan simbol. Ikon merupakan tanda yang bersifat alamiah antara penanda dengan petandanya. Hubungan tersebut adalah hubungan kemiripan. Indeks adalah tanda yang menunjukkan hubungan kausal (sebab-akibat) antara penanda dan petandanya, sedangkan simbol adalah tanda yang bersifat arbitrer. Arti tanda tersebut ditentukan oleh konvensi. Uraian tersebut di atas, memberi isyarat bahwa tanda dengan simbol berbeda dengan fungsinya. Cassier (1987) (dalam Triguna, 2000:8) membedakan antara tanda (sign) dengan simbol (symbol). Tanda bagian "dunia fisik" yang berfungsi sebagai operator yang mempunyai substansial. Sementara simbol merupakan bagian dari dunia makna manusia yang berfungsi sebagai designator. Simbol memiliki nilai fungsional.

Sebuah karya sastra mengandung konvensi bahasa, sastra, dan budaya. Sebuah karya sastra baru mempunyai makna dan menjadi objek estetis bila diberi arti oleh pembaca (Teeuw, 1984:191). Roman Ingarden dan Vodicka (dalam Pradopo, 1995:106), menyatakan pemberian makna terhadap sebuah karya sastra disebut konkretisasi, sedangkan Teeuw (dalam Pradopo, 1995:106) menyatakan pemberian makna terhadap karya sastra disebut naturalisasi atau rekuperasi. Untuk dapat memahami makna budaya yang terdapat dalam Geguritan Dreman, teori semiotik sosial dapat membantu mengungkapkan sebuah teks yang memakai bahasa sebagai tanda (sign), yang mempunyai nilai dan makna tertentu dalam masyarakat tertentu. Dalam hal ini, bahasa dilihat sebagai salah satu dari sejumlah sistem makna yang secara bersama-sama membentuk budaya manusia (Halliday dan Hasan, 1994:5). Untuk dapat memahami karya sastra geguritan secara utuh, perlu dipertimbangkan situasi karya sastra tersebut dalam konteks sosialnya. Dalam tradisi sastra masyarakat Bali, karya sastra geguritan sering dibacakan (di-tembang-kan) dan didengarkan bersama dalam kegiatan mabebasan. Karya sastra berfungsi dalam situasi sosial di samping 
sebagai performing art (Teeuw, 1983:30; 1984:280-281). Fungsi sastra dalam masyarakat Bali tidak dapat lepas dari fungsi sosial, estetik, dan fungsi lainnya, yaitu dalam kegiatan keagamaan.

Untuk lebih memahami karya sastra dalam kehidupan budaya masyarakat tertentu perlu dilakukan pengkajian nilai budaya. Nilai budaya dalam suatu karya sastra ditentukan berdasarkan ciri kesemestaan dan konvensi yang berlaku dalam dimensi waktu penciptaan dan penulisan karya itu. Nilai budaya itu hidup dalam masyarakatnya, sehingga konsepsi-konsepsi itu sejak lama telah berakar dalam alam jiwa mereka. Nilai-nilai didaktik, antropologi, sosial religius, dan psikologi karya sastra memberikan gambaran mengenai wujud konsep-konsep dalam pikiran mereka. Oleh karena itu, nilai-nilai budaya itu sukar diganti dengan nilai-nilai budaya lain dalam waktu yang singkat (Koentjaraningrat, 1993:25-26).

\section{FUNGSI DAN MAKNA GEGURITAN DREMAN}

Imajinasi pembaca memegang peran sangat penting pada saat memahami karya sastra termasuk sastra geguritan. Setiap karya sastra termasuk geguritan menghadirkan suatu dunia imajiner bukan dunia empiris atau suatu kenyataan historis. Ini berarti sastra merupakan fiksi (Kleden, 2004:20; Karmini, 2012). Oleh karena itu, dunia yang dilukiskan dalam Geguritan Dreman adalah fiktif dan tidak perlu dicari kebenarannya dalam dunia nyata. Sebelum sampai pada fungsi dan makna Geguritan Dreman, dipaparkan sinopsisnya terlebih dahulu untuk memberikan gambaran ceritanya.

\section{Sinopsis Geguritan Dreman}

Rumah tangga poligami dikisahkan dalam Geguritan Dreman. Suami bernama I Jati Raga, pandai dan bijaksana, tingkah lakunya terpuji, selalu mendambakan kebaikan. Istri kedua, bernama I Wijasantun, sifatnya buruk, sombong, pemarah, lancang mulut, suka memfitnah, pandai mengada-ada, memakai ilmu magic, tutur katanya lemah lembut tetapi hatinya busuk, namun tetap disayang oleh I Jati Raga. Istri pertama, bernama I Suanggadharmi, sifatnya sangat baik, penyayang, sabar, tidak sombong, taat ajaran agama, rajin berdoa, Wijasantun dianggap sebagai adik. Suanggadharmi tabah dan tenang menghadapi cobaan hidup.
Mereka berpoligami sampai usia tua. Suatu saat I Wijasantun jatuh sakit. Jati Raga dan Suanggadharmi sangat sedih. I Suanggadharmi dengan sabar dan penuh kasih sayang mengobati Wijasantun dengan harapan cepat sembuh, tetapi Wijasantun meninggal. Konon, roh Wijasantun menggigil ketakutan karena dihadang oleh Jogor Manik dan Cikrabala. Rohnya disiksa kemudian digantung pada pohon randu yang di bawahnya terdapat api menyala-nyala. I Jatiraga pun jatuh sakit dan akhirnya meninggal. Rohnya juga mengalami siksaan sesuai dengan perbuatannya dan kemudian dibuang ke dalam jambangan yang berisi air yang mendidih dan di bawahnya terdapat api yang berkobar-kobar.

I Suanggadharmi sangat sedih karena ditinggal oleh orang-orang yang dicintainya. Akhirnya, ia juga meninggal. Rohnya menjadi sangat cantik rupawan serta selalu tersenyum dalam perjalanan menuju surga. Roh yang baik budi ini disambut oleh para bidadari dan para dewata. Namun, roh I Suanggadharmi tetap sedih sebab teringat pada suaminya yang tidak diketahui tempatnya. Roh I Suanggadharmi terus mencari roh Jati Raga. Oleh karena itu, ia tidak mau ke surga. Akhirnya, roh I Suanggadharmi mengetahui keberadaan roh Jati Raga, suaminya. Roh I Suanggadharmi bertekad tetap mengikuti roh suaminya dan menolak diajak ke surga oleh para bidadari dan para dewata. Karena kebulatan tekad Roh I Suanggadharmi untuk tetap mengikuti suaminya, maka Hyang Tuduh (Tuhan) mempertimbangkan hal tersebut. Atas permintaan roh Suanggadharmi, akhirnya roh I Jatiraga dibersihkan serta diizinkan menghuni Surga Loka bersama roh Suanggadharmi, sedangkan roh I Wijasantun tetap disiksa sesuai dengan perbuatannya.

\section{FUNGSI GEGURITAN DREMAN}

\section{Fungsi Struktur Formal Geguritan}

Kata fungsi dalam tulisan ini diartikan sesuai dengan arti yang terdapat dalam KBBI, yakni sebagai 'kegunaan suatu hal' (Alwi, 1996:281). Terkait dengan makna kata fungsi, dalam struktur formal sastra geguritan, terdapat istilah pupuh. Kata pupuh dalam Kamus Bali-Indonesia dimaknai bentuk lagu yang terikat oleh padalingsa, misalnya Sinom, Pangkur. (Warna, 1990:557). Dalam Kamus Besar Bahasa Indonesia (KBBI) kata pupuh dimaknai 'lagu yang terikat oleh banyaknya suku kata dalam 
satu bait, jumlah larik, permainan lagu (Alwi, 1996:799). Dengan demikian dapat dikatakan bahwa fungsi struktur formal geguritan adalah sebagai suatu aturan atau persyaratan yang harus diikuti oleh seorang penulis/penggubah geguritan sesuai dengan pupuh yang digunakan dalam geguritan yang digubahnya.

Geguritan Dreman menggunakan dua pupuh, yaitu pupuh Adri dan pupuh Cecangkriman. Geguritan Dreman dibagi menjadi tiga bagian, yakni bagian I sebanyak 118 bait menggunakan pupuh Adri, bagian II menggunakan pupuh Cecangkriman sebanyak 7 bait, sedangkan bagian III menggunakan pupuh Adri sebanyak 18 bait. Dengan demikian, jumlah bait keseluruhannya adalah 143 bait. Pupuh Adri dan pupuh Cecangkriman termasuk tembang Tengahan. Di bawah ini dikutip Ortenan Tembang Tengahan, khususnya hanya yang digunakan dalam Geguritan Dreman (Karmini, 2008:113).

Tabel 1. Ortenan Tembang Tengahan

\begin{tabular}{cccccccccccc}
\hline No. & Pupuh & Jml.Baris & 1 & 2 & 3 & 4 & 5 & 6 & 7 & 8 & 9 \\
\hline 1. & Adri & 9 & $10 \mathrm{u}$ & $6 \mathrm{e} / \mathrm{a}$ & $8 \mathrm{i}$ & $8 \mathrm{u}$ & $8 \mathrm{u}$ & $8 \mathrm{e}$ & $8 \mathrm{u}$ & $8 \mathrm{a}$ & $8 \mathrm{a}$ \\
\hline 2. & Cecangkriman & 6 & $4 \mathrm{u}$ & $8 \mathrm{u}$ & $6 \mathrm{a}$ & $9 \mathrm{i}$ & $4 \mathrm{u}$ & $8 \mathrm{a}$ & - & - & - \\
\hline
\end{tabular}

\section{Fungsi Pupuh yang Digunakan dalam Geguri- tan Dreman}

Di atas telah dipaparkan makna kata fungsi sesuai KBBI. Fungsi pupuh yang dimaksud pada bagian ini adalah kegunaan sebuah pupuh dalam geguritan yang disesuaikan dengan wataknya. Pada Geguritan Dreman digunakan dua macam pupuh, yaitu pupuh Adri dan pupuh Cecangkriman. Sesuai namanya, yaitu pupuh Adri, adri artinya gunung, tempat yang sangat nyaman, sejuk, memberikan hawa segar, memberikan ketenangan, memberikan keheningan. Sesuai dengan wataknya, yakni pegunungan memberikan hawa sejuk, segar, nyaman, tenang, hening, maka pupuh Adri berfungsi sangat cocok untuk memberikan nasihat, ajaran-ajaran yang bersifat religi sehingga menimbulkan ketenangan, kenyamanan, kepasrahan diri dan pencerahan batin, sedangkan Cecangkriman merupakan syair teka-teki. Cecangkriman menggunakan pupuh Pucung yang dapat digunakan untuk menyampaikan ajaran-ajaran, nasihat-nasihat dengan cara yang ringan. Dengan demikian sesuai wataknya, pupuh Cecangkriman berfungsi untuk menyampaikan ajaran-ajaran, nasihat-nasihat dengan cara ringan (dalam Karmini, 2008:118).

Pada Pupuh Adri 1 yakni dari bait $1-118$ berkisah tentang kehidupan rumah tangga poligami. Pada pupuh Adri 2 yakni dari bait $1-18$ berkisah tentang gambaran-gambaran penderitaan atau siksaan yang dialami di neraka. Pada bagian ini juga disertai nasihat-nasihat bagi orang yang dimadu. Penggunaan pupuh Adri pada geguritan ini sangat tepat sebab sesuai dengan fungsinya, yakni memberikan nasihat, ajaran-ajaran yang bersifat religi sehingga menimbulkan ketenangan, kenyamanan, kepasrahan diri dan pencerahan batin. Pupuh Cecangkriman digunakan dari bait 1-7 berkisah tentang perjalanan roh suci Suanggadarmi yang mencari roh Jati Raga. Setelah ditemukan lalu diangkat dari jambangan (neraka) dan disucikan lalu diajak ke Surga. Penggunaan pupuh Cecangkriman ini sangat tepat sebab berisi tentang ajaranajaran, nasihat-nasihat untuk menjalankan kehidupan. Ajaran-ajaran dimaksud disampaikan dengan cara yang ringan.

\section{Fungsi Gaya Bahasa dalam Geguritan Dreman}

Unsur bahasa sebagai medium dalam karya sastra tidak dapat diabaikan ketika menganalisis sebuah karya sastra. Teeuw (1983:1), menyatakan bahwa analisis terhadap bahasa harus dilakukan mengingat sastra menggunakan bahasa sebagai media. Lebih lanjut, Teeuw (1983:19) juga menyarankan agar dalam menganalisis dan memberi makna sebuah teks sastra, selain diperlukan kode budaya dan kode sastra, perlu juga pengetahuan mengenai kode bahasa. Dalam melakukan analisis terhadap sebuah karya sastra, perlu ada penjelasan pesan atau maksud karya dengan bentuk bahasa yang umum dipakai. Lebih lanjut dinyatakan bahwa ada dua prinsip universal utama yang berfungsi dalam kode bahasa sastra, yaitu prinsip ekuivalensi atau kesepadanan dan prinsip deviasi atau penyimpangan. Efek sastra yang hendak dicapai dalam prinsip kesepadanan (ekuivalensi) ditimbulkan oleh kesepadanan antarunsur bahasa, sedangkan efek kesastraan yang hendak dicapai dalam prinsip penyimpangan (deviasi), ditimbulkan oleh penyimpangan penggunaan bahasa biasa. 
Pada tulisan ini dipandang perlu dibicarakan mengenai gaya bahasa, sebab gaya bahasa merupakan salah satu pembentuk keindahan dalam karya sastra. Pandangan Mulyana disitir oleh Soetarno (1967) (dalam Karmini, 2008:142) menyatakan bahwa gaya bahasa adalah susunan perkataan yang terjadi karena perasaan yang hidup dalam hati pengarang, yang menimbulkan perasaan tertentu dalam hati, sedangkan Keraf (1981) (dalam Karmini, 2008:142) menyatakan gaya bahasa sebenarnya merupakan bagian dari pilihan kata yang mempersoalkan cocok-tidaknya pemakaian kata, frase atau klausa tertentu, untuk menghadapi situasi-situasi tertentu. Dengan demikian, jangkauan gaya bahasa sebenarnya sangat luas, bukan hanya meliputi unsur-unsur kalimat saja. Berkaitan dengan itu, maka di bawah ini dipaparkan hanya beberapa gaya bahasa yang paling dominan digunakan dalam teks Geguritan Dreman.

\section{Gaya bahasa Persamaan atau Simile dalam Geguritan Dreman}

Gaya Persamaan atau Simile adalah perbandingan yang bersifat eksplisit, yang langsung menyatakan sesuatu sama dengan hal yang lain. Untuk itu digunakan kata: seperti, sama, sebagai, bagaikan, laksana. Gaya Simile ini terdapat dalam teks Geguritan Dreman. Di bawah ini dikutip beberapa contoh gaya Simile dalam Geguritan Dreman

..., Wijasekar mawak guna, saksat ipun Rangden Jirah (bait 45 pupuh Adri 1).

Dalam kutipan tersebut, pengarang membandingkan Wijasantun dengan Rangda Jirah, karena Wijasantun menggunakan guna-guna untuk menundukkan suaminya supaya patuh kepada dirinya. Rangda Jirah dipergunakan sebagai perbandingan karena ia sangat menguasai ilmu hitam dalam cerita Calon Arang. Rangda Jirah disebut juga Calon Arang adalah tokoh perempuan dari Jirah yang bila marah atau tersinggung, ia dapat melakukan apa saja dengan ilmu hitamnya untuk menyakiti orangorang termasuk membunuhnya.

...,madun Gusti Suanggadarma, saksat toya upaminya (bait 59 pupuh Adri 1).

Kutipan tersebut di atas, digunakan oleh pengarang untuk membandingkan kebaikan-kebaikan I Sanggadarmi yang seperti air (saksat toya). Air dapat memberikan kesejukan, menghapus dahaga semua ciptaan Tuhan tanpa pilih kasih, tanpa membedakan yang baik atau pun yang buruk.

\section{Gaya Hiperbola dalam Geguritan Dreman}

Gaya hiperbola adalah gaya bahasa yang mengandung suatu pernyataan yang berlebihan, dengan membesar-besarkan suatu hal. Gaya ini terdapat dalam Geguritan Dreman yang contohnya dipaparkan di bawah ini.

..., genit uyang mabiluluk, tuara jenek di padu

nung,...(bait 55 pupuh Adri 1).

Kutipan di atas menyatakan sesuatu yang dibesarbesarkan, yakni gatal (genit) luar biasa yang menyebabkan sangat gelisah (uyang). Kegelisahan yang luar biasa seolah-olah sampai bergulingguling (mabiluluk).

\section{Gaya Personifikasi dalam Geguritan Dreman}

Personifikasi adalah semacam gaya bahasa kiasan yang menggambarkan benda-benda mati atau barang-barang yang tidak bernyawa seolah-olah memiliki sifat-sifat kemanusiaan. Benda-benda tersebut dapat bertindak, berbuat, berbicara seperti manusia. Gaya ini terdapat dalam Geguritan Dreman.

$$
\begin{aligned}
& \text {...,"Kadung titiang labuh ujar, baktin titiange } \\
& \text { masomah" (bait } 114 \text { pupuh Adri 1). }
\end{aligned}
$$

Kutipan di atas, yakni yang menyatakan bahwa kata-kata telah ke luar, yang berarti sebagai sebuah janji yang harus ditepati (labuh ujar). Labuh ujar (secara harfiah berarti jatuh kata) dikategorikan gaya personifikasi sebab ujar (ucapan) bisa bertindak seperti manusia, yakni labuh (jatuh).

\section{MAKNA GEGURITAN DREMAN}

\section{Makna Hiburan}

Sastra geguritan merupakan sastra tembang karena pembacaannya disampaikan lewat alunan irama yang indah yang disebut macapat. Irama dimaksud dapat menggugah penghayatan seseorang terhadap isi geguritan yang sarat dengan makna dan sekaligus memberi hiburan. Hal ini sesuai dengan konsep malajah sambilang magending, magending sambilang malajah (belajar sambil bernyanyi, bernyanyi sambil belajar) (Karmini, 2008:3; 2012:143).

Pernyataan yang terkait dengan "hiburan" sering ditemukan dalam teks geguritan yang mengungkapkan bahwa menggubah geguritan merupakan "kegiatan iseng". Contoh dalam Geguritan Ni Candrawati dinyatakan bahwa menggubah geguritan tujuannya untuk menghibur hati yang sedih, yang dinyatakan dengan ... I rika ngawe cerita, manah 
Sasedih, kidung anggen mamurnayang (...saat menulis cerita, hati sedih, lagu dipakai untuk menghibur) (bait 1, pupuh Ginada). Namun, tidak semua geguritan diawali dengan pernyataan bahwa menulis geguritan sebuah hiburan atau sebuah kegiatan iseng. Ada yang menggubah geguritan diawali dengan pernyataan bahwa menggubah geguritan dengan tujuan dapat digunakan sebagai pedoman dalam menghadapi suka duka hidup di dunia ini. Contoh dalam Geguritan Dreman ... sangkannya mungguh ring kidung, tingkahe dadi jeleme, linging sastra jua tutut, anggon sepate ring raga, tingkahe mapaumahan (... itu sebabnya ada dalam lagu/pupuh, cara berperilaku sebagai manusia, isi sastra (ajaran) diikuti, dipakai teladan cara berperilaku dalam berumah tangga (bait I:1 pupuh Adri). Contoh lain dalam Geguritan Diah Sawitri yang dinyatakan dengan ...tur sida kanggen panuntun, jroning nyanggra suka duhka, maring jagate puniki (... juga bisa dipakai teladan saat menghadapi suka duka kehidupan di dunia ini (bait 1, pupuh Sinom). Dan satu contoh lagi, yakni Geguritan Damayanti dinyatakan bahwa menggubah geguritan dengan tujuan dapat digunakan sebagai pedoman dalam menjalani hidup ini, yang dinyatakan dengan ...mogi kasidan, 'nggen sesuluh jroning $\operatorname{urip}(\ldots$ mudah-mudahan bisa dipakai sebagai cermin selama hidup) (bait 1, pupuh Durma). Pada pernyataan penyair tersebut di atas, tersirat makna indah dan bermanfaat atau berguna sehingga pembaca terpengaruh atau digerakkan untuk bertindak. Pernyataan tersebut senada atau sejalan dengan istilah Horatius, yakni seniman bertugas untuk docere dan delectare, serta movere yakni memberi ajaran dan kenikmatan serta menggerakkan pembaca ke kegiatan yang bertanggungjawab. Sastra yang mampu menggerakkan dan mampu mempengaruhi pembaca sangat sesuai dengan pernyataan Horace tentang fungsi sastra sebagai dulce et utile (menyenangkan dan berguna). Karena itu, seni harus menggabungkan sifat utile dan dulce, yakni yang bermanfaat dan yang manis atau yang enak (Teeuw, 1984:51; Pradopo, 1997: 6; Karmini, 2008:3). Berdasarkan uraian di atas, dapat dinyatakan bahwa geguritan merupakan suatu karya sastra tradisional yang sanggup memberikan hiburan sekaligus besar manfaatnya serta sangat berharga bagi kehidupan penikmatnya.

\section{Makna Pembelajaran Hidup dan Kehidupan Pembelajaran tentang Tri hita karana}

Dalam Geguritan Dreman tersirat adanya pembelajaran tentang tri hita karana. Tri hita karana menurut I Gusti Ketut Kaler terdiri atas kata tri yang artinya 'tiga', hita artinya 'baik, senang, gembira, lestari', dan karana artinya 'sebab-musabab' atau 'sumbernya sebab'. Dengan demikian, tri hita karana berarti 'tiga buah unsur yang merupakan sumbernya sebab yang memungkinkan timbulnya kebaikan'(dalam Karmini, 2008:161). Unsur-unsur tri hita karana menurut I Nengah Sudharma (dalam Karmini, 2008:162), adalah (1) Sang Hyang Widhi, yang merupakan super natural power, (2) bhuwana, yang merupakan macrocosmos, (3) manusia, yang merupakan microcosmos. Ketiga unsur tersebut tidak dapat dipisahkan dalam tata hidup masyarakat Hindu di Bali. Ketiga unsur tersebut senantiasa diterapkan dan dilaksanakan pada setiap aspek kehidupan secara harmonis dan dinamis.

Tri hita karana (dalam Karmini, 2008:162), mengajarkan pola hidup seimbang di antara ketiga sumber kesejahteraan dan kedamaian hidup. Manusia selalu berusaha untuk menjaga keharmonisan hubungan di antara ketiga unsur dimaksud, yaitu (1) hubungan manusia dengan Tuhan, (2) hubungan manusia dengan alam, (3) hubungan manusia dengan manusia. Dalam pandangan masyarakat Hindu, hubungan manusia dengan Tuhan dikonsepsikan sebagai kaula (yang dikuasai) dan gusti (yang menguasai). Hubungan ini melahirkan paham 'Tuhan sebagai Sang sangkan paraning dumadi' atau 'Tuhan sebagai asal dan tujuan hidup manusia'. Dari hubungan tersebut muncul kesadaran untuk bhakti yang menumbuhkan loyalitas untuk mengabdi. Rasa bhakti masyarakat Hindu diwujudkan dalam bentuk yadnya yang ditujukan kepada Sang Hyang Widhi Wasa. Dalam hubungan manusia dengan alam, manusia membedakan alam menjadi dua, yakni alam nyata dan alam tidak nyata/alam gaib. Paham subjektif masyarakat Hindu tampak dari konsepsi bhuana agung dan bhuana alit. Konsepsi ini didasari oleh ide dasar, yaitu 'ide kesatuan'. Manusia harus melakukan penyatuan terhadap alam secara serasi, selaras, dan seimbang. Karena itu muncul kesadaran identifikasi terhadap alam. Manusia identik dengan alam sehingga manusia adalah alam juga. Karena itu pula, alam semesta disebut bhuana agung dan diri manusia disebut bhuana alit. 
Sifat identik tersebut terlihat pada dikotomis, yaitu pada manusia ada unsur purusa (Atman) yang merupakan unsur aktif dan unsur prakerti (pradana), yaitu badan wadah yang merupakan unsur pasif. Pada alam semesta ada unsur Paramatman (Tuhan) sebagai purusa, yaitu unsur aktif dan bumi sebagai unsur prakerti, yaitu unsur pasif. Atman dan Paramatman kualitasnya sama yang ditunjukkan dengan ucapan 'Brahman Atman Aikyam' (dalam Karmini, 2008:163). Gusti Agung Gede Putra dan Gusti Ketut Kaler menyatakan bahwa keserasian hubungan manusia dengan alam diumpamakan 'kadi manik ring cecupu' (seperti janin dan rahim ibu), yang maksudnya adalah manusia hidup dilingkupi oleh alam dan dari alam manusia memperoleh sarana untuk hidup. Dari perumpamaan tersebut, tampaknya manusia bebas mengambil apa saja dari alam, tetapi manusia terikat oleh kewajiban untuk tidak merusak alam, sebab alam rusak berarti dirinya pun akan rusak. Pola ikatan 'manik ring cecupu' ini selanjutnya dipakai sebagai anutan dalam hidup bermasyarakat umat Hindu di Bali (dalam Karmini, 2008:164). Dalam hubungan antara manusia dengan manusia, kehidupan masyarakat Hindu di Bali didasarkan atas asas yang disebut tat twam asi. Secara harfiah tat artinya 'itu' (ia), twam artinya 'kamu' dan asi artinya 'adalah'. Jadi, tat twam asi artinya 'itu (ia) adalah kamu'. Tat twam asi mengandung makna yang luas dan dalam. Di dalamnya terkandung suatu ajaran dan dasar kesusilaan untuk dikembangkan dalam pergaulan hidup antar sesama makhluk. Prinsip dasar tat twam asi dalam kehidupan masyarakat Hindu di Bali dikonsepsikan ke dalam asas: suka duka, paras paros, salunglung sabayantaka, dan asas saling asih, saling asuh, saling asah (dalam Karmini, 2008:164-165).

Setelah dicermati, maka Geguritan Dreman dapat dikatakan memuat makna dari konsep tri hita karana, yakni menyangkut hubungan manusia dengan Tuhan, hubungan manusia dengan alam (lingkungan), dan hubungan manusia dengan manusia. Sebenarnya, secara tersurat konsep tri hita karana tidak ada, tetapi secara tersirat konsep tersebut ada dalam geguritan. Hal ini tercermin dalam tujuan hidup para tokoh cerita, yakni moksartham jagathitaya ca iti dharmah, maksudnya, tujuan dharma adalah untuk mencapai kesejahteraan di dunia ini dan di dunia lain.

\section{Pembelajaran tentang Panca çradha}

Pembelajaran mengenai panca çradha tercermin dalam Geguritan Dreman. Panca çradha meliputi: (1) percaya adanya Sang Hyang Widhi (Tuhan Yang Mahaesa), (2) percaya adanya Atma, (3) percaya adanya hukum karma phala, (4) percaya adanya samsara (punarbhawa), (5) percaya adanya moksa (dalam Karmini, 2008:165-166).

\section{1) Percaya adanya Sang Hyang Widhi}

Percaya pada Sang Hyang Widhi tercermin dalam Geguritan Dreman. Dalam Geguritan Dreman tersirat keyakinan bahwa manusia mati karena rohnya diambil oleh Kala Mretiu yang merupakan manifestasi Tuhan. Sebagai contoh, hal itu dinyatakan pada pupuh Adri bait ke- 79 .

Kaget rauh Dewa Kala Mretiu, mangalap uripe, rauhnyane tan pajati, I Dreman twara da tau, pesu girang kenyung-kenyung, mengkah-mengkuh di palingihan, aturan teka matulu, who-wohan sasanganan, rupanyane malegendah.

Artinya:

Tiba-tiba Dewa Kala Mretiu (manifestasi Tuhan yang bertugas mencabut nyawa) datang tanpa pemberitahuan, Dreman pun tidak tahu bahwa nyawanya akan dicabut saat itu, pada saat ia sedang sangat bahagia, tersenyum-senyum karena bermacam-macam hidangan buah dan jajan ada di hadapannya sebagai makanan saat akan tidur

\section{2) Percaya adanya Atma}

Atma adalah merupakan percikan-percikan dari Paramatman yaitu Sang Hyang Widhi. Manusia dihidupkan oleh Atma. Atma dan badan ini ibarat kusir dengan kereta (dalam Karmini, 2008:169). Percaya pada adanya Atma tersurat dan tersirat dalam Geguritan Dreman. Pada bait 89 Geguritan Dreman diungkap tentang kematian Wijasantun yang rohnya disiksa, bait 100 tentang kematian I Jatiraga yang rohnya juga disiksa, bait 103 sampai 118 pupuh Adri 1, bait 1 sampai 7 pupuh Cecangkriman, dan bait 1 sampai 18 pupuh Adri 2 tentang kematian dan perjalanan Atma I Suanggadarmi.

\section{3) Percaya adanya hukum karma phala}

Karma phala artinya hasil perbuatan. Karma phala dibedakan menjadi tiga macam, yaitu (1) sancita, (2) prarabda, dan (3) kriyamana. Sancita ialah phala dari perbuatan dalam kehidupan dahulu yang belum habis dinikmati dan merupakan benih yang 
menentukan kehidupan sekarang. Prarabda, ialah phala dari perbuatan pada kehidupan ini tanpa ada sisanya lagi. Kriyamana, ialah hasil perbuatan yang tidak sempat dinikmati pada saat berbuat, sehingga harus diterima pada kehidupan yang akan datang (dalam Karmini, 2008:169).

Keyakinan tentang karma phala tercermin dalam Geguritan Dreman. Dalam Geguritan Dreman jelas tersurat dan tersirat bahwa perbuatan baik berpahala baik, sedangkan perbuatan buruk berpahala buruk. Dengan adanya pernyataan di atas, penikmat dapat mengambil sikap dan dapat memutuskan perbuatan yang mana yang dipilihnya dan dijadikan pedoman dalam menjalani hidup dan kehidupan ini. Karma phala yang tercermin dalam geguritan ini adalah sancita kriyamana. Hal ini tersurat pada bait ke-16 dan bait-bait yang menyatakan perjalanan roh I Wijasantun, I Jatiraga dan I Suanggadarmi setelah mereka meninggal. Berikut ini dikutip hanya bait ke-16 pupuh Adri.

Pakretine aba uli malu, sangkan nemu jele, apane jua rasaning, pangrasane awak Eluh, tau teken tumbuh eluh, sok becik jani gawenang, tau awak tumbuh lacur, sampun mangiwangin somah, istri kawawa ajadnya.

Artinya:

Hasil perbuatan di masa lalu, makanya mengalami yang tidak baik, apalagi perasaan perempuan merasa jadi perempuan, perbuatan baik yang dilakukan, memahami diri sengsara, jangan menyalahkan suami, karena istri milik suami

\section{4) Percaya adanya samsara (punarbhawa)}

Punarbhawa atau samsara ialah kelahiran berulang-ulang, yang disebut juga dengan penitisan. Penitisan ini membawa akibat suka duka. Punarbhawa terjadi karena atma masih dipengaruhi oleh kenikmatan dunia (dalam Karmini, 2008:170). Keyakinan ini (punarbhawa) tercermin dalam Geguritan Dreman dan di dalamnya dipaparkan bahwa jika lahir kembali banyak hal yang dialami sesuai perbuatan yang dilakukan. Hal ini dinyatakan pada bait-bait akhir cerita, yakni bait 14, 15, 16, 17, 18 pupuh Adri.

\section{5) Percaya adanya moksa}

Moksa menjadi tujuan agama (dharma). Moksa berarti kebebasan dari ikatan keduniawian, bebas dari karma phala, bebas dari samsara. Moksa tidak hanya dicapai setelah meninggal tetapi dapat pula dicapai di dunia ini. Moksa di dunia hanya dapat dicapai jika sudah bebas dari ikatan-ikatan duniawi yang disebut dengan jiwan mukti (moksa semasih hidup). Cara mencapai moksa di dunia adalah dengan jalan berbakti kepada dharma dalam arti seluas-luasnya (dalam Karmini, 2008:171). Moksa di dunia tersirat dalam Geguritan Dreman.

\section{Pembelajaran tentang Etika}

Etika atau susila adalah ajaran tentang tingkah laku. Tingkah laku dapat dikategorikan ke dalam tingkah laku yang baik (subha karma) dan tingkah laku yang tidak baik (ashuba karma). Tingkah laku yang baik (subha karma), meliputi: tat twam asi, tri kaya parisuda, dasa nyama brata, dan dasa yama brata, sedangkan tingkah laku yang tidak baik (asubha karma/asusila), meliputi: sad ripu, sapta timira, sad tatayi.

\section{Tingkah laku baik atau subha karma \\ 1) Tat twam asi}

Tat twam asi sebagai salah satu ajaran subha karma berarti "aku adalah engkau, engkau adalah aku". Kalimat ini berarti bahwa kita wajib mengasihi orang lain seperti kita mengasihi diri sendiri. Hal ini sebagai dasar utama untuk mewujudkan masyarakat yang santi (damai) dan kerta (makmur). Karena itu, tat twam asi harus dilaksanakan dengan cinta kasih, bakti dan rela berkorban (dalam Karmini, 2008:171).

Ajaran tat twam asi yang dilaksanakan dengan cinta kasih, bakti dan rela berkorban dapat dilihat pada Geguritan Dreman bait ke- 11, 12, 13, 27, 28, 30, $38,40,42,43,54,55,56,64,68,69,77,84,90$ pupuh Adri. Di bawah ini dikutip bait 11 sebagai contoh.

I Suanggadarmi bangkit satuwuk, tanporat awake, idepang jua masih bangkit, twara lali teken tutur, astiti baktine malu, sayangan masih rabine, diati masih magantung, yan luas satibapara, rabine hestiyang jumah.

Artinya:

Suanggadarmi selalu bangkit, berat sekali hidup ini, harus selalu bangkit, jangan lupa pada ajaran, dan selalu berdoa, suami harus disayang, karena merasa bergantung, andai bepergian, suami selalu didoakan 


\section{2) Tri kaya parisuda}

Tri kaya parisudha merupakan tiga laksana baik, yang meliputi kayika (tingkah laku yang baik), wacika (perkataan yang baik), dan manacika (pikiran yang baik). Kayika merupakan tiga macam pengendalian diri dalam bertingkah laku, yakni tidak membunuh (ahimsa), tidak mencuri, tidak berzina. Wacika merupakan empat macam pengendalian melalui perkataan, yakni tidak mencaci maki orang lain, tidak berkata kasar walaupun benar atau sebaliknya tidak berkata lembut tetapi dusta, tidak memfitnah, dan tidak ingkar janji. Manacika merupakan tiga macam pengendalian diri melalui pikiran, yakni tidak menginginkan sesuatu yang tidak halal, tidak berpikir buruk terhadap orang lain, dan tidak mengingkari hukum karma phala (dalam Karmini, 2008:173). Tri kaya parisudha tersirat pada perilaku I Suanggadarmi. Perilakunya itu tersurat pada bait-bait yang berkisah tentang I Suanggadarmi. Perilaku I Suanggadarmi baik, karena itu, ia memperoleh Surga setelah meninggal dan mampu menolong atau mengangkat I Jatiraga (suaminya) dari neraka.

\section{3) Dasa niyama brata}

Dasa niyama brata adalah sepuluh pengendalian diri atau sikap mental. Dasa niyama brata, meliputi: dana yaitu pemberian sedekah, ijya artinya hormat atau memuja kepada leluhur dan Hyang Widhi, tapa artinya melatih diri untuk mencapai ketenangan hati, dyana artinya memusatkan pikiran kepada Hyang Widhi, swadhyaya artinya tekun mempelajari ajaran-ajaran suci, upasthanigraha artinya mengendalikan hawa nafsu, brata artinya taat kepada sumpah atau janji, upawasa artinya berpuasa, mona artinya membatasi perkataan, snana artinya melakukan pensucian diri (dalam Karmini, 2008:175). Dalam Geguritan Dreman tercermin ajaran dasa niyama brata. Ajaran ini dilaksanakan oleh tokoh I Suanggadarmi.

\section{4) Dasa yama brata}

Dasa yama brata adalah sepuluh pengendalian atau pengekangan hawa nafsu. Dasa yama brata, meliputi: anresangsya atau arimbawa artinya tidak mementingkan diri sendiri, ksama artinya suka mengampuni dan tahan uji dalam kehidupan, satya artinya setia, ahimsa artinya tidak membunuh, dama artinya dapat menasihati diri sendiri, ardjawa artinya jujur mempertahankan kebenaran, priti artinya cinta kasih kepada sesama makhluk, prasada artinya berpikir dan berhati suci tanpa pamerih, madurya artinya ramah tamah, lemah lembut, mardawa artinya rendah hati (dalam Karmini, 2008:175). Dalam Geguritan Dreman, ajaran dasa yama brata dilaksanakan oleh tokoh I Suanggadarmi.

\section{Tingkah laku yang tidak baik (asubha karma) 1) Sad ripu}

Sad ripu termasuk tingkah laku yang tidak baik (asubha karma/asusila). Sad ripu adalah enam perbuatan yang tidak layak dilakukan, yang meliputi: kama ialah perbuatan yang didorong oleh hawa nafsu, kroda/murka adalah sifat pemarah, lobha adalah sifat rakus, moha adalah sifat kebingungan dan angkuh, mada adalah sifat suka mabuk, matsarya adalah sifat iri hati (dalam Karmini, 2008:176). Perbuatan tidak baik karena pengaruh sad ripu dilakukan oleh tokoh I Wijasantun dalam Geguritan Dreman.

\section{2) Sapta timira}

Sapta timira adalah tujuh macam perbuatan yang disebabkan oleh kegelapan pikiran/mabuk, yang termasuk juga ke dalam tingkah laku yang tidak baik (asubha karma/asusila). Sapta timira meliputi: surupa artinya mabuk karena rupa tampan atau cantik, dana artinya mabuk karena kekayaan, guna artinya mabuk karena kepandaian, kulina artinya mabuk karena kebangsawanan/keturunan, yowana artinya sifat sombong karena merasa muda dan kuat, sura artinya mabuk karena minuman keras, kasuran artinya mabuk kemenangan (dalam Karmini, 2008:177). Tingkah laku yang tidak baik karena dipengaruhi sapta timira khususnya surupa, guna, yowana tercermin dalam Geguritan Dreman.

\section{3) Sad tatayi}

Sad tatayi adalah enam perbuatan kejam. Ini juga merupakan bagian dari tingkah laku yang tidak baik (asubha karma/asusila). Sad tatayi meliputi: agnida artinya membakar milik orang lain, wisada artinya meracuni orang lain, atharwa artinya melakukan ilmu hitam atau guna-guna, sastraghna artinya mengamuk, dratikarama artinya memperkosa kehormatan orang lain, rajapisuna artinya memfitnah (dalam Karmini, 2008:177). Perbuatan kejam atau sad tatayi tersurat dalam Geguritan Dreman. Perbuatan kejam yang dilakukan adalah melakukan ilmu hitam atau guna-guna (atharwa) dan memfitnah (rajapisuna). Perbuatan ini dilakukan oleh tokoh I Wijasantun. 


\section{PEMBAHASAN}

Pembelajaran tentang tri hita karana, panca çradha, etika terutama subha karma yang disebutkan di atas, patut dipedomani dan dijadikan pengendali diri, apalagi pada zaman ini, yakni zaman Kali. Pada zaman Kali banyak bermunculan pikiranpikiran libral, banyak orang mengesampingkan moralitas dalam pergaulan. Banyak manusia yang tidak mampu lagi membeda-bedakan dan tidak bisa menimbang-nimbang antara yang baik dan buruk. Manusia dikuasai keinginan-keinginan yang berlebihan sehingga muncul keserakahan yang tidak terkendalikan. Keinginan dan keserakahan yang berlebihan itulah dapat menjatuhkan martabat.

Sebagai makhluk sosial, seseorang tidak dapat lepas hubungan dengan orang lain. Karena itu, kata-kata (wacika) yang merupakan salah satu bagian dari ajaran tri kaya parisudha memegang peranan sangat penting dalam menentukan selamat dan celakanya kehidupan seseorang di dunia ini. Seperti dinyatakan dalam Niti sastra (V.3) sebagai berikut.

Waçita nimittanta manēmu laksmi

Waçita nimittanta manēmu duhka

Waçita nimittanta pati kapangguh

Waçita nimittanta manēmu mitra

Artinya:

Karena perkataan engkau akan mendapatkan kebahagiaan

Karena perkataan engkau akan mendapat kesusahan

Karena perkataan engkau akan menemui ajal

Karena perkataan engkau akan mendapat sahabat

(dalam Karmini, 2008:179)

Dalam Manawa Dharmasastra dinyatakan bahwa karma yang lahir dari pikiran, perkataan, dan badan berakibat baik atau buruk. Karma menyebabkan bermacam-macam keadaan pada diri manusia. Perbuatan baik atau buruk dari tingkah laku badan berakibat pada tingkah laku perbuatan badan, perbuatan pikiran berakibat pada pikiran, dan perbuatan perkataan berakibat pada perkataan. Dosa akibat perbuatan badan akan menjadi benda mati kelak, dosa akibat perkataan akan menjadi burung atau binatang buas kelak, dan dosa akibat pikiran akan lahir ke kelahiran yang rendah kelak (dalam Karmini, 2008:179).

Dengan demikian, makna yang tersirat dalam Geguritan Dreman dapat digunakan sebagai pembelajaran tentang etika hidup dan kehidupan.
Dapat dijadikan pedoman dan teladan dalam menjalankan kehidupan ini. Jika seseorang mampu menghayatinya, tentu dalam diri seseorang muncul suatu prinsip yang kuat, yang mampu menunjukkan harkat, martabat, dan jati dirinya, serta muncul kemampuan yang luar biasa untuk mengendalikan diri.

\section{SIMPULAN}

Geguritan Dreman ternyata merupakan karya sastra Bali tradisional yang kaya ajaran yang dapat dijadikan pedoman dalam menjalani kehidupan. Di dalamnya tersurat dan tersirat ajaran Tri hita karana, panca çradha, dan ajaran tentang etika. Ajaran tentang etika terutama subha karma (tingkah laku yang baik), meliputi: tat twam asi, tri kaya parisuda, dasa nyama brata, dan dasa yama brata sangat baik diteladani dan dijadikan pedoman hidup, sehingga terbentuk karakter baik yang menunjukkan harkat, martabat, dan jati diri. Ajaran asubha karma (tingkah laku yang tidak baik) sebaiknya tidak ditiru sebab dapat menjerumuskan diri sendiri.

\section{DAFTAR RUJUKAN}

Alwi, Hasan. (1996). Kamus Besar Bahasa Indonesia. Edisi Kedua. Balai Pustaka, Jakarta.

Bandem, I Made dan Sal Murgiyanto. (1996). Teater Daerah Indonesia. Kanisius, Yogyakarta.

Danandjaja. James. (1997). Folklor Indonesia. Pustaka Utama Grafiti, Jakarta.

Halliday, M.A.K. dan Ruqaiya Hasan. 1994. Bahasa, Konteks, dan Teks: Aspek-aspek Bahasa dalam Pandangan Semiotik Sosial. Terjemahan dari Language, Contex, and Text: Aspects of Language in a Social-semiotik Perspective. Penerjemah Drs. Asrudin Barori Tou, M.A. Yogyakarta: Gajah Mada University Press.

Kaplan, David dan Robert A.Manners. (2002). Tori Budaya. Pustaka Pelajar, Yogyakarta.

Karmini, Ni Nyoman. 2002. "Geguritan Sarasamuscaya: Analisis Bentuk, Fungsi, dan Makna". Tesis. Universitas Udayana, Denpasar. 
Karmini, Ni Nyoman. (2008). "Sosok Perempuan dalam Teks Geguritan di Bali: Analisis Feminisme". Disertasi Program Doktor Linguistik. Universitas Udayana, Denpasar.

Karmini, Ni Nyoman. 2011a. Teori Pengkajian Prosan Fiksi dan Drama. Pustaka Larasan bekerja sama dengan Saraswati Institut Press, Denpasar.

Karmini, Ni Nyoman. 2011b. "Geguritan Diah Sawitri: Inspirasi Kemandirian Bagi Perempuan Bali". Dimuat dalam jurnal terakreditasi B LIPI, No. 337/AU1/P2MBI/04/2011. Sawerigading: Jurnal Bahasa dan Sastra, Volume 17, Edisi Khusus, Oktober 2011, hlm.45-56, ISSN08544220. Balai Bahasa Ujung Pandang, Makassar.

Karmini, Ni Nyoman. 2012. "Analisis Feminisme dalam Geguritan Saci." Dimuat dalam jurnal terakreditasi Dikti, Mudra, Jurnal Seni Budaya, Volume 27, No. 2 Juli 2012, hlm 141-154, ISSN:0854-3461. Institut Seni Indonesia, Denpasar.

Karmini, Ni Nyoman. 2015a. "Tingkatkan Kualitas Kehidupan dengan Memahami Kreativitas Manusia”. Dimuat dalam jurnal Suluh Pendidikan (Jurnal Ilmu-Ilmu Pendidikan), Volume 13, Nomor 1 Juni 2015, hlm.1-10, ISSN 1829-894X. LPPM IKIP Saraswati, Tabanan.

Karmini, Ni Nyoman. 2015b. "Narasi Kesetiaan demi Keutuhan Rumah Tangga dalam Sastra Bali:: Analisis "Geguritan Bali". Dimuat dalam jurnal terakreditasi B Menristek Dikti No.12/KP/II/2015, tanggal 11 Februari 2015, Jurnal Kajian Bali, Journal of Bali Studies, Volume 05, Nomor 01, April 2015, hlm.143-164, ISSN 2088-4443. Universitas Udayana, Denpasar.

Karmini, Ni Nyoman. 2015c. "Value Education in Literature Tradisional Bali as the Establishment of Reference Characters". Dimuat dalam International Journal of Science and Research (IJSR). Volume 4, Issue 11, November 2015. Paper ID NOV151488, page 1566-1568, ISSN (online) 2319-7064, Index Copernicus Value (2013): 6.14, Impact Factor (2014):5.611.Licensed Under Creative Commons Attribution CCBY. www.ijsr.net.

Karmini, Ni Nyoman. (2016). "Analysis the Meaning of Geguritan Dyah Arini" Dimuat dalam International Journal of Science and Research (IJSR). Volume 5, Issue 1, Januari 2016. Paper ID NOV152878, ISSN (online) 2319-7064, p.938-941, Index Copernicus Value (2013): 6.14, Infact Factor (2014): 5.611, Licensed Under Creative Commons Attribution CC BY, www.ijsr.net

Kleden, Ignas. (2004). Sastra Indonesia dalam Enam Pertanyaan. Anggota IKAPI, Jakarta.
Koentjaraningrat. (1993). Kebudayaan Mentalitas dan Pembangunan. Gramedia Pustaka Utama, Jakarta.

Luxemburg, J.v., Mieke Bal dan Willem G. Weststeijn. 1992. Pengantar Ilmu Sastra. Gramedia Pustaka Utama, Jakarta.

Teeuw, A. 1983. Membaca dan Menilai Sastra. Gramedia, Jakarta.

Teeuw, A. (1984). Sastra dan Ilmu Sastra. Pustaka Jaya, Jakarta.

Teeuw, A. (2003). Sastra dan Ilmu Sastera. Pustaka Jaya, Jakarta.

Suwija, I.K. 1979. “Mengenal Prasi”. Gedong Kirtya, Singaraja.

Putra, I Nyoman Darma. 2009. ''Kidung Interaktif' Vocalising and interpreting traditional literature through electronic mass media in Bali', Indonesia and the Malay World, 37:109, pp. 249-276.

Putra, I Nyoman Darma. 2010. Tonggak Baru Sastra Bali Modern. Pustaka Larasan, Denpasar.

Putra, I Nyoman Darma. 2011a.'Politik Identitas dalam Teks Sastrawan Bali" dimuat dalam Jurnal Kajian Bali, Volume 01, Nomor 01, April 2011, ISSN2088-4443. Universitas Udayana.

Putra, I Nyoman Darma. 2011b. A literary Mirror; Balinese Reflections on Modernity and Identity in the Twentieth Century. Leiden: KITLV Press.

Pradopo, R. D. 1995. Beberapa Teori Sastra, Metode Kritik, dan Penerapannya. Pustaka Pelajar, Yogyakarta.

Putra, I Nyoman Darma. 2010. Tonggak Baru Sastra Bali Modern. Pustaka Larasan, Denpasar.

Putra, I Nyoman Darma. 2011a.'Politik Identitas dalam Teks Sastrawan Bali" dimuat dalam Jurnal Kajian Bali, Volume 01, Nomor 01, April 2011, ISSN 2088-4443. Universitas Udayana.

Putra, I Nyoman Darma. 2011b. A literary Mirror; Balinese Reflections on Modernity and Identity in the Twentieth Century. Leiden: KITLV Press.

Triguna, Yudha. I.B.G. 2000. Teori Tentang Simbol. Widya Dharma, Denpasar.

Warna, I.W. 1990. Kamus Bali-Indonesia. Dinas Pendidikan Dasar Provinsi. Bali. 